KARINA GIEL

Uniwersytet im. Adama Mickiewicza w Poznaniu

ORCID: 0000-0002-4637-7757

e-mail: kagiel@amu.edu.pl

\title{
ŚRODKOWODALMATYŃSKIE KONTAKTY JĘZYKOWE W PSICH PRZYPOWIASTKACH MILJENKA SMOJE. ZAPOŻYCZENIA LEKSYKALNE W GWARZE MIEJSKIEJ SPLITU
}

Przedmiot mojej pracy stanowią zapożyczenia leksykalne w gwarze miejskiej Splitu. Badania przeprowadziłam na podstawie utworu prozaicznego Miljenka Smoje Pasje novelete ('Psie przypowiastki')'.

Tekst ten jest interesujący przede wszystkim ze względu na zagadnienie wpływów obcych w środkowej Dalmacji, które nie zostało dotąd wyczerpująco zbadane. Oprócz tego na uwagę zasługuje fakt, że pisarz posługuje się językiem miejskim Splitu, różniącym się znacznie od potocznej odmiany chorwackiego języka ogólnego.

Pogląd, że języki nie pozostają w izolacji, ale przenikają się jednostronnie bądź wzajemnie, nie stanowi obecnie żadnego novum. Nie ma języka o strukturze całkowicie homogenicznej, co wynika z oczywistego faktu, że społeczność językowa nie jest na ogół zamknięta w sobie, ale wchodzi w kontakty ze społecznościami posługującymi się innymi systemami językowymi, które z kolei przeważnie też nie są w swym składzie homogeniczne, gdyż w obrębie tej społeczności zawsze znajdują się jednostki czy nawet grupy mówiące nie tylko językiem ojczystym, ale także posługujące się czynnie lub biernie innymi językami. Same kontakty językowe są najczęściej następstwem czynników pozajęzykowych - politycznych, ekonomicznych, kulturowych, naukowych. Natomiast ich rezultaty, utrwalone w danym języku jako wpływy obce, są jednym z przejawów innowacji, które pojawiają się stale w każdym żywym języku oraz są dowodem na dążenie języka do samodoskonalenia - m.in. poprzez uzupełnianie luk semantycznych w systemie lub stanowią przykład pewnej mody językowej na zapożyczenia.

Język chorwacki w ciągu swojego rozwoju odznaczał się wielką chłonnością, swoistą ,gościnnością" w stosunku do wyrazów obcych. Gwałtownymi falami, choć

\footnotetext{
${ }^{1}$ Książka została wydana w 2001 roku w Splicie nakładem wydawnictwa Feral Tribune.
} 
z różną siłą, wdzierały się do tego języka wyrazy łacińskie, włoskie, niemieckie, francuskie, węgierskie, angielskie, tureckie, a nawet czeskie. Słownictwo odzwierciedla intensywne kontakty Chorwatów z innymi narodami, rejestruje w swym zasobie skutki wielowiekowych wpływów politycznych, gospodarczych i kulturalnych.

Zebrany materiał wyrazowy skonfrontowałam z odpowiednimi opracowaniami leksykologicznymi i słownikami etymologicznymi2. W opisie posługuję się metodą statystyczną. Ze względu na obszerność materiału ograniczyłam przykłady zapożyczeń z niektórych języków obcych do wyrazów o najwyższej frekwencji.

Rozumienie terminu zapożyczenie przejęłam od Małgorzaty Witaszek-Samborskiej, która stwierdza, iż „,za zapożyczone w danym języku uważa się te elementy, które nie są wynikiem rozwoju elementów odziedziczonych z prajęzyka, lecz weszły do języka z zewnątrz, zostały przejęte z innych języków" (Witaszek-Samborska 1993: 14). Przedmiotem mojego artykułu są głównie typowe zapożyczenia; derywaty od zapożyczeń są rzadko udokumentowane.

Dialekty chorwackie i oparte na nich języki regionalne zapożyczały obcą leksykę w różnych okresach dziejowych. Dziś na wszystkie dialekty coraz silniej oddziałuje język angielski. Wiele z wyrazów obcego pochodzenia, zapożyczonych niegdyś przed dialekty, uważa się obecnie za regionalizmy, co dowodzi, że nie przedostały się one do słownictwa standardowego (Samardžija 1995: 48). Znajdziemy ich też niemało w Psich przypowiastkach.

W tym miejscu warto przedstawić zarys historii kontaktów językowych na interesującym nas obszarze.

\section{Wpływy romańskie - włoskie i francuskie}

Geopolityczne położenie Chorwacji na granicy między Wschodem i Zachodem okazało się decydującym czynnikiem w kształtowaniu się chorwackiej tożsamości kulturowej. W badaniu chorwacko-romańskich kontaktów językowych szczególną uwagę należałoby zwrócić na geograficzny obszar Chorwacji przymorskiej, tutaj bowiem doszło do bezpośrednich kontaktów dialektów chorwackich z dialektami włoskimi i językiem włoskiego piśmiennictwa. Chorwacja kontynentalna natomiast uczestniczyła w tych kontaktach zwykle za pośrednictwem innych języków, co ostatecznie zaowocowało stosunkowo małą liczbą italianizmów w leksyce języka standardowego.

Najdawniejsze ślady pojawienia się w dzisiejszej Dalmacji ludności romańskiej sięgają czasów przed Chrystusem. Ostatecznego podboju całego kraju Ilirów Rzymianie dokonali za cesarza Oktawiana (Podhorodecki 2000: 9); wówczas to rozpoczęła

${ }^{2}$ Należy zaznaczyć, iż niejednokrotnie spotykałam się z sytuacją, w której źródła różnie interpretują pochodzenie poszczególnych wyrazów. Etymologię poszczególnych wyrazów ustalałam na podstawie słowników wymienionych w bibliografii. Pochodzenie leksyki niestandardowej ustalałam na podstawie materiału przykładowego, zebranego w publikacjach na temat zapożyczeń z poszczególnych języków. Jeżeli dany wyraz nie był notowany w żadnej z dostępnych mi publikacji, wówczas starałam się ustalić język źródłowy, posługując się polską bibliografią oraz słownikami poszczególnych języków obcych. 
się intensywna kolonizacja zdobytych obszarów. Niesprzyjające warunki historyczne (w tym najazdy barbarzyńców ${ }^{3}$ ) uniemożliwiły intensywne kontakty kulturowe z Rzymem, co przyczyniło się do ukształtowania odrębnego języka, opartego na dialekcie łacińskim. Tak powstał język dalmatyński. Z nim zetknęli się Słowianie, którzy zaatakowali terytorium ludności romańskiej. $Z$ pewnością doszło do kontaktów językowych między tymi grupami ludności, a ostatecznie do slawizacji Dalmatyńczyków. W XII wieku mieszkańcy miast dalmatyńskich to w znacznej większości Chorwaci (Sočanac 2004: 60).

O wyparciu języka dalmatyńskiego z użycia zadecydowało ostatecznie zwycięstwo Wenecji nad Zadarem w 1243 roku. W konsekwencji Wenecjanie przesiedlali do miast dalmatyńskich swoich obywateli i obsadzali nimi najwyższe stanowiska, dotychczas zajmowane przez dalmatyński patrycjat. W ten sposób wenecki dialekt języka włoskiego zaczął nawarstwiać się na język dalmatyński.

W XIII wieku dialekt wenecki był obecny jedynie w mowie szlachty przesiedlonej z Wenecji, z czasem jednak zaczął się pojawiać w różnych kręgach życia publicznego, początkowo współistniejąc z językiem dalmatyńskim. W krótkim czasie okazało się, że opłacało się znać język nowych kolonizatorów, gdyż przynosiło to konkretne korzyści (Muljačić 1962: 243). I wkrótce miastami dalmatyńskimi zawładnął język Wenecjan. Po wywalczeniu dominacji na morzu język państwa weneckiego staje się swoistym międzynarodowym językiem handlu. L. Sočanac nazywa go lingua franca nie tylko na obszarze Dalmacji, ale na całym Adriatyku i Półwyspie Bałkańskim (Sočanac 2004: 90). W ten sposób wzmagały się wpływy Wenecjan w obcym, słowiańskim środowisku, co naturalnie znalazło odbicie w języku Chorwatów (Hamm 1961: 75).

Silna pozycja i wszechobecność dialektu weneckiego zostają zachwiane dopiero w XV wieku. Od tego czasu stopniowo zaczyna wzrastać rola pozostałych dialektów włoskich w rozwoju chorwackiej leksyki. Mieszkańców Dalmacji przybywają do Włoch ze względu na możliwości kształcenia się, stąd chorwaccy studenci pojawiają się w Bolonii i Padwie. Po latach nauki wracają oni w rodzinne strony ze znajomością nowego języka - literackiego języka włoskiego opartego na dialekcie toskańskim. Tak więc dialekt wenecki nawarstwił się na pozostałości języka dalmatyńskiego, ale sam był stopniowo wypierany przez dialekt toskański (Muljačić 1962: 341).

Zapożyczanie leksyki włoskiej ma miejsce w ograniczonym stopniu również dzisiaj. Młodzi ludzie w Dalmacji często uczą się języka włoskiego - w ten sposób rodzi się szczególny typ fascynacji i sympatii dla włoskich elementów językowych, które przenikają do języka chorwackiego, choć w rzeczywistości nie są mu już potrzebne. Nie jest to wywołane potrzebą języka, lecz podobnie jak w wypadku anglicyzmów pewnego rodzaju modą.

Jeżeli chodzi o chorwacko-francuskie kontakty językowe, to trzeba zauważyć, iż w swojej historii język chorwacki rzadko miał okazję do bezpośrednich kontaktów z językiem francuskim. Jednakże przez lata język ten był językiem dyplomacji i wyróżnikiem wysokiego statusu społecznego, co wyjaśnia szerokie rozpowszechnienie

${ }^{3}$ Chodzi o najazdy Wizygotów, Hunów, Ostrogotów, Gepidów i Longobardów (Podhorodecki 2000: 12-13). 
francuskich pożyczek w całej Europie, w tym także w Chorwacji oraz w gwarach środkowej Dalmacji. Galicyzmy przenikały do języka chorwackiego głównie za pośrednictwem innych języków.

\section{Wpływy germańskie - niemieckie i angielskie}

O umocnieniu związków chorwacko-niemieckich zadecydował wybór Ferdynanda I Habsburga na króla Chorwacji. Najintensywniejsze kontakty zaznaczyły się w okresie politycznej zależności państwa chorwackiego od monarchii habsburskiej i z krótszymi lub dłuższymi przerwami trwają one do dzisiaj. Dalmacja była bezpośrednio podporządkowana Wiedniowi, co w pewien sposób wiązało ją silniej z Austrią niż z pozostałymi ziemiami Królestwa Chorwackiego. Jednak język chorwacki już od średniowiecza kontaktował się z rozmaitymi odmianami terytorialnymi języka niemieckiego. O ich intensywności można już mówić w XIII wieku, kiedy to niemieccy handlarze przybywali na ziemie chorwackie, w krótkim czasie zostawiając ślad w kulturze miejskiej całej Chorwacji, docierając również na obszary Dalmacji (Gojmerac 2001: 181). Germanizmy wchodziły do języka chorwackiego głównie za pośrednictwem wojska (tu doniosłą rolę w szerzeniu języka niemieckiego na ziemie Chorwacji odegrał obszar Vojnej Krajiny; Gojmerac 2001: 182) i administracji, ale także drogą handlu i nauki (Peco 1986: 281-282). Szlachta i bogate mieszczaństwo uważały naukę i używanie języka niemieckiego za symbol wysokiego statusu, natomiast kupcy i handlarze posługiwali się tym językiem z powodów czysto praktycznych (Glovacki-Bernardi 1993: 93).

Po zwycięstwie kontrreformacji do Chorwacji zaczęła napływać, oprócz kupców i handlarzy, szlachta i drobna inteligencja, głównie lekarze, aptekarze i urzędnicy. Liczbę niemieckich imigrantów powiększyli dodatkowo chłopi z Bawarii, Szwabii i Frankonii, którzy zasiedlali ziemie Slawonii oraz południowych Węgier, opustoszałe po wycofaniu się wojsk tureckich (Gojmerac 2001: 182).

W okresie komunizmu władze podsycały przekonanie, iż narzucona siłą germanizacja poczyniła wiele szkód w języku (Gojmerac 2001: 181), stając się dla w zakresie leksyki zjawiskiem niekorzystnym i niepożądanym. W tym okresie dominowała propagowana przez władze opinia, iż język niemiecki to po prostu język okupantów i nazistów (Gojmerac 2001: 190), co na jakiś czas ograniczyło napływ germanizmów do języka chorwackiego. Współcześnie germanizmy szerzą się na terenach zamieszkiwanych przez powracających z Niemiec i Austrii „gastarbajterów”, którzy emigrowali $\mathrm{w}$ drugiej połowie stulecia i w czasie wojny w latach dziewięćdziesiątych. $\mathrm{W}$ języku potocznym zapożyczenia te wypierają nawet wyrazy rodzimego pochodzenia (Peco 1986: 272). Warto jednak podkreślić, iż obecna popularność germanizmów ograniczona jest do pewnych sfer leksyki, a ich użycie ma często wymiar lokalny.

Uwagi o statusie anglicyzmów w języku chorwackim należałoby zacząć od przypomnienia faktu, iż język angielski jest językiem, którym dziś posługuje się 57 milionów Brytyjczyków. Ponadto 300 milionów ludzi na czterech kontynentach korzysta z niego jako języka rodzimego lub języka komunikacji. Co szósty człowiek na naszej planecie używa angielszczyzny jako języka obcego bądź się go uczy. W ciągu 
ostatnich kilku dekad językowi angielskiemu udało się znacznie ograniczyć rolę języka francuskiego w dyplomacji i niemieckiego w biznesie. Nic więc dziwnego, że w krótkim czasie stał on się językiem międzynarodowej komunikacji (Novaković-Šašić 1996: 307).

Wśród zapożyczeń właściwych, przenikających współcześnie do języka chorwackiego, zapożyczenia angielskie zajmują bezspornie pierwsze miejsce. Proces ten obserwujemy mniej więcej od lat 50. XX wieku (Samardžija 1995: 144). W dobie powszechnej globalizacji język angielski staje się za pośrednictwem masowych mediów językiem światowym i przenika do mowy mieszkańców całego globu.

Wśród anglicyzmów występują nie tylko wyrazy etymologicznie angielskie, ale również słownictwo innego pochodzenia, angielszczyzna bowiem często pośredniczy w złożonym kontakcie języków europejskich z językami egzotycznymi. Przykład tego rodzaju pośrednictwa można zauważyć także w Psich przypowiastkach Smoje, np. w przejętym $z$ języka hindi słowie šampon. $Z$ pewnością można dzisiaj mówić o modzie na angielszczyznę, zwłaszcza w takich dziedzinach, jak informatyka, technika, życie gospodarcze i polityczne, sport, muzyka, media oraz kultura młodzieżowa. Dynamiczny rozwój tych dziedzin prowadzi do konieczności poszukiwania nowej leksyki na określanie dotychczas nieznanych zjawisk. Z powodu postępującej globalizacji proces zapożyczania $\mathrm{z}$ angielskiego trwa nadal.

\section{Wpływy orientalne}

Najintensywniejsze kontakty języka chorwackiego z językiem tureckim datują się od ekspansji militarnej Turków na ziemie południowosłowiańskie. Turcy rozpoczęli swoje podboje na Bałkanach już w połowie XIV wieku (w 1352 roku), ale dopiero klęska wojsk chorwackich i węgierskich w bitwie pod Mohaczem w roku 1526 otworzyła im drogę do Chorwacji, głównie do jej części północnej i zachodniej. ${ }^{4} \mathrm{~W}$ ten sposób Turcy pojawili się także w Dalmacji, a okupacja tych terenów trwała do pokoju w Karłowicach, tj. do 1699 roku. Warto dodać, że Turkom nigdy nie udało się zdobyć Splitu, Dubrownika, Omisza, Trogiru, Szibenika, Zadaru i Senja.

Najwięcej tureckich pożyczek przeniknęło do języka chorwackiego w okresie od XV do XVII wieku (na obszary południowe nawet do XIX stulecia), gdy Bałkany znajdowały się pod silnym wpływem politycznym Turcji (Brborić 1996: 344-345). Jak zauważył P. Skok, turecka cywilizacja nie mogła nie wywrzeć wpływu na ówczesną cywilizację wiejską Słowian, którym kultura ta imponowała (Skok 1938: 174).

Zapożyczenia tureckie nie przenikały w jednakowej mierze do wszystkich dialektów chorwackich. Ze względu na bliskość geograficzną najbardziej podatny na przenikanie turcyzmów okazał się dialekt sztokawski, a najmniej - czakawski. Dlatego wiele zapożyczeń pochodzenia tureckiego, które znajdujemy dzisiaj w mowie czakawców, można by zaliczyć do zapożyczeń międzydialektalnych. Najlepszym dowodem na to może być fakt, iż wszystkie wyekscerpowane przeze mnie z tekstu Smoje

\footnotetext{
${ }^{4}$ Turcy nie dotarli do północno-zachodnich obszarów Dalmacji, na wyspy i na Istrię.
} 
turcyzmy są leksemami standardowymi, używanymi na całym obszarze chorwackim. Popularność turcyzmów w standardzie chorwackim wzrosła bowiem wraz z przyjęciem dialektu sztokawskiego za podstawę chorwackiej normy językowej.

\section{Wpływy węgierskie}

Kontakty Chorwatów z Węgrami sięgają w daleką przeszłość i datowane są na IX wiek, kiedy to plemiona madziarskie osiedliły się na obszarze Panonii. Jednakże dopiero średniowiecze zbliżyło na dłużej oba narody. Na mocy umowy zwanej Pacta conventa lub Qualiter, zawartej w 1102 roku, Chorwacja i Węgry połączyły się w unii personalnej (Perić 1997: 52). Ta decyzja zaważyła na losach obu państw na długie stulecia i określiła kształt ich polityki, społeczeństwa, kultury, a także języka.

Węgrzy starali się umocnić administracyjną jedność ziem chorwackich i węgierskich, domagając się czynnej znajomości języka węgierskiego od urzędników, kleru i oficerów. Pragnęli stworzyć silne państwo narodowe, które wchłonęłoby około 70\%, tj. 5,6 mln ludności niemadziarskiej (Skowronek 1977: 234), w ogromnej większości słowiańskiej. Oprócz Chorwatów z Chorwacji, Slawonii i Dalmacji znaleźliby się w nim także Serbowie, Słoweńcy, Czesi i Słowacy. Dlatego też wielokrotnie dochodziło do konfliktów między obu państwami, których następstwem były liczne bunty i ruchy antywęgierskie. Stan ciągłego napięcia politycznego pomiędzy Chorwacją i Węgrami zadecydował o silnej antypatii, co skutecznie blokowało napływ węgierskiej leksyki do języka chorwackiego. Po ośmiu wiekach wspólnej historii obu narodów liczba madziaryzmów we współczesnych chorwackich słownikach jest stosunkowo niewielka.

Jak zauważa J. Jerković, literatura naukowa na temat zapożyczania przez języki serbski i chorwacki słownictwa pochodzenia węgierskiego jest skromna, co uniemożliwia wyczerpujące opracowanie tego zagadnienia (Jerković 1996: 173). Autor artykułu odnalazł w Rečniku srpskohrvatskog književnog jezika (Rečnik: 1967) 177 wyrazów pochodzenia węgierskiego.

Jak się okazuje, język węgierski nie oddziaływał silniej na żaden ze słowiańskich języków, które weszły z nim w kontakt. Najwięcej madziaryzmów przejął język słowacki (Reychman 1947: 205), za pośrednictwem którego część z nich przeniknęła także do języka polskiego.

\section{Ogólna charakterystyka statystyczna zapożyczeń w utworze M. Smoje}

$\mathrm{Na} 124$ stronach tekstu, zawierającego 22996 wyrazów, znajduje się 628 haseł obcego pochodzenia; 1542 użycia tych haseł stanowią 6,7\% wszystkich wyrazów w książce.

Aż 441 haseł wyrazowych to rzeczowniki - 70,22\% wszystkich zapożyczeń. Udział liczbowy i procentowy pozostałych części mowy przedstawia się następująco: 
87 czasowników (13,85\%), 77 przymiotników (i imiesłowów przymiotnikowych) (12,26\%), 17 przysłówków (2,7\%), 2 liczebniki, 2 wykrzykniki oraz 1 zaimek i 1 przyimek.

Pod względem liczby haseł zdecydowanie dominują pożyczki włoskie. Kolejne miejsca zajmują: internacjonalizmy, galicyzmy, anglicyzmy, germanizmy, turcyzmy oraz madziaryzmy, następnie hybrydy, pożyczki z greki i łaciny. Italianizmy i internacjonalizmy zdecydowanie dominują zarówno pod względem liczby haseł, jak i użyć w tekście.

Na liście frekwencyjnej użyć poszczególnych zapożyczeń również dominują pożyczki włoskie. Dalej mamy internacjonalizmy, galicyzmy, anglicyzmy i turcyzmy, a dopiero za nimi germanizmy. Kolejne miejsca zajmują zapożyczenia z greki i języka węgierskiego, hybrydy i na końcu pożyczki łacińskie.

Co 15 słowo w wykorzystanym tekście jest wyrazem zapożyczonym. Wyrazy te maja różną frekwencję -23 możliwości od $\mathrm{f}=81$ do $\mathrm{f}=1$. Średnia frekwencja hasła obcego pochodzenia wynosi 2,45. Najwięcej haseł występuje w częstotliwościach najniższych.

Najwięcej jest haseł $\mathrm{z}$ frekwencją $\mathrm{f}=1$ - 393; stanowią one aż 62,57\% wszystkich haseł zapożyczonych, jednakże suma ich użyć stanowi zaledwie 25,48\% całościowego użycia wyrazów obcego pochodzenia w tekście.

Zapożyczenia użyte przynajmniej 20 razy (tj. 8 haseł) wystąpiły łącznie 284 razy, co stanowi niemalże 18,42\% wszystkich użyć wyrazów zapożyczonych. Hasła poświadczone przynajmniej 10 razy odnotowane są 469 razy, a więc stanowią 30,41\% wszystkich użyć wyrazów obcego pochodzenia. Natomiast 35 najczęstszych haseł (powyżej 6 użyć) pojawia się w tekście 615 razy i stanowi 39,88\% użyć wszystkich zapożyczeń.

$\mathrm{Na}$ podstawie rangi oraz frekwencji można obliczyć tzw. iloczyn Estoupa-Zipfa, który pokazuje zależność między częstotliwością danego hasła a jego rangą i wyraża się wzorem $\mathrm{C}=\mathrm{r} * \mathrm{f}$ (Smółkowa 1974: 86.). Iloczyn ten stopniowo wzrasta aż do $\mathrm{r}=8$, po którym przez 5 pozycji frekwencyjnych utrzymuje mniej więcej stały poziom, by po $\mathrm{r}=13$ stopniowo opadać aż do końca listy.

Końcowe obliczenia pozwalają stwierdzić, iż wyrazy obcego pochodzenia o najniższych frekwencjach od $\mathrm{f}=1$ do $\mathrm{f}=3$ mają większe znaczenie dla słownika utworu (aż 85,33\% haseł zapożyczonych!) niż jego tekstu (46,81\%). Zdecydowaną większość zapożyczeń stanowią więc wyrazy rzadkie oraz wyjątkowo użyte.

\section{Italianizmy}

Przywiązanie Smoje do języka włoskiego przejawia się nie tylko w licznych zapożyczeniach, ale także w całych fragmentach tekstu bezpośrednio zaczerpniętych z włoskiego, np. Ti pagera per tuto! ('Ty jesteś wszystkiemu winien!').

Jeśli chodzi o statystykę, odnotowałam aż 283 hasła pochodzenia włoskiego (zarówno toskańskiego, jak i weneckiego) i kilkakrotnie dalmatyńskiego. Stanowią one 45,06\% wszystkich zapożyczeń. Procent ich użycia jest jeszcze wyższy: 896 użyć stanowi 58,1\% wszystkich użyć wyrazów obcego pochodzenia i 3,89\% wszystkich 
wyrazów w książce. Liczby te świadczą o dużym udziale italianizmów w sferze języka potocznego, związanego z codzienną ludzką egzystencją. Sześć kolejnych leksemów o najwyższej frekwencji to italianizmy: kompanjo (81 razy) 'towarzysz', Punta (45 r.) 'czubek, szpic' (tu: w funkcji nazwy własnej lokalnego cypla), ura (30 r.) 'godzina', teraca (28 r.), fin (27 r.) 'miły, ładny', kužina (26 r.) 'kuchnia'. Do pozostałych zapożyczeń o wysokiej frekwencji zalicza się takie wyrazy jak: kantun (15 r.) 'kąt', tinel (15 r.) 'pokój gościnny’, šjor (14 r.) 'pan', vižita (14 r.), spiza (13 r.) 'jedzenie', banda (11 r.), krepat (11 r.) 'zdychać', pijat (11 r.) 'talerz', skale (10 r.) 'schody', bura (9 r.) 'bora', sigurno (9 r.), dišpet (8 r.) 'złośliwość', feta (8 r.) 'plasterek', panceta (8 r.) 'boczek', pišat (8 r.) 'siusiać', dotur (7 r.) 'lekarz', mortadela (7 r.), pulenta (7 r.) 'polenta', finta (6 r.) 'trik', furešt (6 r.) 'cudzoziemiec', manistra (6 r.) 'zupa', šjora (6 r.) 'pani'. Po 5 użyć dotyczy następujących haseł: barbun 'brzanka', beštija 'zwierzę, bestia', butiga 'sklep', deboto 'natychmiast', gušt 'przyjemność', guštat 'delektować się', kvarat 'ćwierć, kwadrans', marun 'kasztan', miritat 'zasłużyć', noweleta 'przypowiastka', parit 'wydawać się', penšjunat 'emeryt', skula 'szkoła', šporak 'brudny', šugaman 'ręcznik', trevit 'spotkać'. Po 4 użycia mają hasła: atentno 'uważnie', buža 'dziura', fermat se 'zatrzymać się', infotat se 'rozgniewać się', injekcjun 'zastrzyk', makinjeta 'maszyna', partit 'wyjeżdżać', pinjata 'garnuszek', rekuperavat 'dochodzić do zdrowia', šinjorina 'panienka', skaline 'schodki', škivat 'unikać', štorija 'opowiadanie', štuf 'znudzony', štufat 'znudzić się', vižitavat 'badać'.

\section{Internacjonalizmy}

Dla potrzeb pracy internacjonalizmy podzielono na internacjonalizmy właściwe, które zostały zapożyczone z języków klasycznych (greka i łacina), oraz zapożyczenia sztuczne, czyli internacjonalizmy, które upowszechniały się, funkcjonując, w ramach systemu takich języków europejskich, jak angielski, francuski, włoski i niemiecki.

\section{Internacjonalizmy właściwe}

Internacjonalizmy właściwe to 144 hasła, co stanowi aż 77,01\% wszystkich internacjonalizmów i 22,92\% wszystkich pożyczek. Pojawiają się w tekście 212 razy, co stanowi 69,97\% wszystkich użyć internacjonalizmów, 13,75\% użyć zapożyczeń i 0,92\% ogółu wyrazów tekstu.

Najwyższą frekwencję mają następujące wyrazy: auto (25 r.), veterinar (12 r.), minuta (7 r.), kilo (6 r.), vila (6 r.). Leksemy porat 'port' i tonobil 'samochód' pojawiły się w tekście po 5 razy, kontra oraz problem po 4 razy, anđel, frustriran, ordinacija, reagirat, veterinarski po 3 razy. Po 2 razy natomiast wystąpiły w tekście: apetit, civiliziran, diskretan, eventualno, evidencija, historiografija/istoriografija, ideja 'pomysł', injekcija, inštitut, karta, kriza 'kryzys', likvidirat, nacionalista, nimfomanka, plebejac 'plebejusz', reuma 'reumatyzm', scena, situacija, vitamin. 


\section{Zapożyczenia sztuczne}

Leksemy należące do tej grupy to 43 hasła, co stanowi 22,99\% wszystkich internacjonalizmów i $6,84 \%$ wszystkich zapożyczeń z języków obcych. W tekście pojawiają się 91 razy, co stanowi 30,03\% wszystkich użyć internacjonalizmów, 5,9\% użyć pożyczek w tekście i 0,39\% ogółu wyrazów w książce. Jest wśród nich 16 leksemów powstałych na gruncie francuskim: centimetar, delikates, humanitaran, komplet, kompletan, kompromitirat, metar, panika, paničariti, panično, penzioner 'emeryt', plastičan, reklama, reklamirat, rezultat, sentimentalniji, 9 wywodzących się z języka angielskiego: fotoreporter, gen, letrika 'elektryka', telefon, telefonirat, telefonski, televizija, tranzistor, radijo, $8 \mathrm{z}$ języka włoskiego: baritonski, fašizam, figurin 'elegancik', firma, komunjara 'komunista', rasizam, rasistički oraz 7 pożyczek z języka niemieckiego: kalibar 'kaliber', kombinat, kombinatorika, kombiniran 'złożony z kilku elementów', kriminal, raritet 'rarytas', torta 'tort'. Wyraz pop słowniki uważają za bezpośrednią pożyczkę z języka rosyjskiego lub ukraińskiego, które to języki zapożyczyły wyraz z języka greckiego. W przypadku języka chorwackiego należałoby dopuścić możliwość serbskiego pośrednictwa.

W tekście najczęściej pojawiają się następujące wyrazy: telefon (5 r.), komunjara (4 r.) centimetar (3 r.), kompletan (3 r.). Po 2 użycia dotyczą wyrazów: firma, fotoreporter, humanitaran, kombinat, panika, pop, rasistički, sentimentalniji, telefonirat, telefonski, televizija, torta. Pozostałe zapożyczenia sztuczne pojawiają się w tekście zaledwie raz.

\section{Galicyzmy}

Galicyzmy zajmują w książce Smoje trzecie miejsce pod względem liczby haseł, zaraz po italianizmach i internacjonalizmach. 67 haseł stanowi 10,66\% wszystkich haseł obcego pochodzenia. Użycie galicyzmów przedstawia się następująco: 138 użyć stanowi $8,94 \%$ wszystkich użyć wyrazów obcego pochodzenia oraz $0,6 \%$ wszystkich wyrazów w tekście. Najwyższą frekwencję mają takie wyrazy, jak: dama (11 r.), frižider (7 r.) 'lodówka', turistički (7 r.), inženjer (6 r.), šarmirat (6 r.) 'oczarować'. Hasła fotelja, paket 'paczka', turizam pojawiły się 4 razy, lavativ 'lewatywa' - 3 razy, bazen, boem 'przedstawiciel cyganerii', bon-ton, interesantan, komitet, modni, Partija ('partia'; autor stosuje tu pisownię godnościową w odniesieniu do Związku Komunistów Jugosławii), plan, rafiniran 'wyrafinowany', randevu 'randka', romantičan, salon, šofer i žurnal wystąpiły 2 razy. Pozostałe galicyzmy pojawiają się w tekście tylko raz: adresa, angažiran 'zaangażowany, zatrudniony', avancirat 'awansować', banalan, bonboncini 'cukiereczek', dresirat 'tresować', dresura, finesa 'subtelność', garderoba, kadra, klošar 'kloszard', kontrolirat, kreten 'kretyn', madam, marširat, minijatura, moda, model, moderan, monsinjor, montirat, otel 'hotel', otelski 'hotelowy', parafinski, partija, pejsaž, planirat, plastičan, pledoaje, premijer, reportaža, repriza 'powtórka, dokładka', restoran 'restauracja', resurs 'bogactwo naturalne', roman 'powieść', rutina, ruža, šampanjac, seansa, suveren, suverenitet, teren, terorist, tirada, toaleta, tuširat 'brać prysznic'. 


\section{Anglicyzmy}

Wyekscerpowałam 24 hasła, co stanowi 3,82\% wszystkich haseł obcego pochodzenia. Użycie haseł pochodzenia angielskiego przedstawia się następująco: 64 użycia stanowią 4,15\% wszystkich użyć wyrazów obcego pochodzenia i $0,27 \%$ wszystkich wyrazów w książce. Statystykę użyć niewątpliwie podnoszą trzy anglicyzmy: bungalov (15 r.), šampon (12 r.) oraz vikendica (10 r.) 'dacza', które stanowią 57,81\% użyć wszystkich anglicyzmów w tekście. Wśród innych anglicyzmów mamy: kontejner (4 r.) 'pojemnik' oraz pozostałe hasła, które pojawiają się po 2 razy: demejana 'gąsior na wino', koktel 'koktajl', standard lub tylko 1 raz: biznis, bum, dendi 'dandys', farma, film, hit, keks 'ciasto', koker-španjel, koled 'szkoła wyższa', livorver 'rewolwer', partnerica, rapidan 'gwałtowny', štrajk 'strajk', štrajkat, striptiz, tenis, vikend.

\section{Germanizmy}

Badając germanizmy, nie brałam pod uwagę tych wyrazów germańskiego pochodzenia, które zostały zapożyczone jeszcze w epoce języka prasłowiańskiego, przed migracją na Bałkany, a więc są dziś znane wszystkim językom słowiańskim. Znalazłyby się wśród nich wówczas następujące pożyczki: kralj 'król', crkva 'kościół', daska 'deska', krst 'krzyż'.

Wśród późniejszych germanizmów znajduje się 21 haseł i stanowią one 3,34\% wszystkich zapożyczeń z języków obcych. Do tej liczby można by dodać jeszcze kilka internacjonalizmów oraz wyrazów o niepewnej etymologii, które prawdopodobnie przeniknęły do chorwackiego za pośrednictwem języka niemieckiego. Germanizmy leksykalne w utworze Smoje występują rzadko - 36 użyć stanowi zaledwie $2,33 \%$ wszystkich użyć zapożyczeń i $0,15 \%$ wszystkich wyrazów w tekście. Myślę, że ten stan rzeczy należałoby objaśnić dominującą rolą języka włoskiego w Dalmacji, który ma tu na tyle ugruntowaną pozycję, iż użytkownicy chorwackiego nie odczuwają potrzeby zastępowania go innymi środkami wyrazu. Nieliczne germanizmy odnoszą się w większości przypadków do wymienionych przeze mnie dziedzin życia, takich jak wojsko (montura 'mundur'), handel (fabrikant 'producent') czy sport (fuzbališt 'piłkarz'). Większość z nich to nacechowane pejoratywnie kolokwializmy: hoštapler 'hochsztapler', šminker 'pozer', uncut 'huncwot'. Ostatni wyraz niewątpliwie został zapożyczony za pośrednictwem węgierskim. Najwyższą frekwencję ma wyraz papa 'tata', wywodzący się z łaciny. Pojawia się on w tekście 4 razy. 3 razy poświadczone są słowa: deka 'koc', njuferica 'dziewica' oraz špica 'szczyt, szpic', natomiast po 2 użycia mają hoštapler, krafen 'pączek', raznjuferit 'pozbawić dziewictwa', šprenga 'strzał', šunka 'szynka' i uncut. Pozostałe germanizmy pojawiają się w tekście zaledwie 1 raz: ementaler, fabrikant, fuzbališt, gemišt 'mieszanka wina i wody', montura, morgen 'jutro', plakat, sic 'siedzenie', šminker, štruca 'bochen', šupirat 'wygnać'. 


\section{Orientalizmy \\ (z języka staroosmańskiego, arabskiego \\ i perskiego przez język turecki)}

Ze zbioru nowel Smoje wynotowałam 18 haseł pochodzenia tureckiego, w tym jedno hasło pojawia się w dwóch wariantach - kava / kafa. Hasła te stanowią 2,86\% wszystkich haseł obcego pochodzenia w tekście. Na podobnym poziomie plasuje się użycie turcyzmów w tekście: jest ich 45, co stanowi 2,91\% wszystkich użyć pożyczek i 0,19\% wszystkich wyrazów Psich przypowiastek.

Większość turcyzmów poświadczona jest zaledwie 1 raz. Chodzi tutaj o następujące hasła: alat 'narzędzie', bovan 'kamień, čizmica 'bucik', duvan 'tytoń', emirat, katram 'smoła', pazarić 'ryneczek', suđuk 'kiełbasa z papryką i cebulą', šeik 'szejk', šeikat 'szejkanat'. Dwukrotnie wystąpiły wyrazy: muzuvir 'oszust, kłamca' oraz zeman 'czas', natomiast wyraz žep 'kieszeń' pojawił się 3 razy. Częściej pojawiły się leksemy: kafa / kava (4 r.), papuča (4 r.) 'kapeć', pazar (4 r.) 'rynek', kafana (6 r.) 'kawiarnia' oraz kafić (11 r.) 'kafeteria, kawiarenka'. Biorąc pod uwagę fakt, że Smoje opisuje w książce swoją codzienną egzystencję, łatwo zrozumieć, dlaczego te właśnie wyrazy cechuje najwyższa frekwencja.

\section{Madziaryzmy}

Utwór Smoje poświadcza jedynie 5 wyrazów pochodzenia węgierskiego, co stanowi zaledwie 0,79\% wszystkich haseł. Jeszcze skromniej przedstawia się użycie tych haseł, pojawiają się one bowiem zaledwie 6 razy, co stanowi 0,38\% wszystkich użyć wyrazów obcego pochodzenia i 0,02\% wszystkich wyrazów w książce. Czasownik kenjat 'załatwiać się' pojawia się w tekście 2 razy, pozostałe wyrazy zostały użyte 1 raz. Są to 3 rzeczowniki: beteg 'choroba', čopor 'stado', gulaš oraz 1 przymiotnik baršunast 'atłasowy', utworzony za pomocą sufiksu -ast od odpowiedniego rzeczownika węgierskiego.

\section{Hybrydy}

Cztery hybrydy stanowią zaledwie $0,6 \%$ wszystkich haseł. Pojawiają się one jedynie 5 razy, co stanowi 0,32\% wszystkich użyć zapożyczeń i 0,02\% wszystkich wyrazów tekstu. Oprócz leksemu jugonostalgičar 'tęskniący za czasami dawnej Jugosławii', który występuje w tekście 2 razy, pozostałe hybrydy poświadczone są jednokrotnie: jugonostalgija, jugokomunistički oraz panslavizam.

\section{Charakterystyka semantyczna zapożyczeń}

W celu przybliżenia semantyki zapożyczeń, zakwalifikowano je do grup wyodrębnionych zgodnie z podziałem na części mowy. 


\section{Rzeczowniki}

Wśród rzeczowników można wyróżnić następujące grupy realno-znaczeniowe:

- nazwy abstrakcyjne (182 hasła, tj. 41,27\% wszystkich rzeczowników obcego pochodzenia), np.: diškorš 'przemówienie', egzistencija, konverzacija;

- nazwy ludzi (75 haseł, tj. 17\%), np.: enciklopedist, klošar, kompanjo;

- nazwy zwierząt (7 hasel, tj. 1,59\%), np.: bakalar 'dorsz', barbun, koker-španjel;

- nazwy roślin (2 hasła, tj. 0,45\%): duvan, marun;

- nazwy przedmiotów (175 haseł, tj. 39,68\%); tu m. in.:

- nazwy miejsc: bungalow, pazar, teraca;

- kulinaria: bržola 'pieczeń', ementaler, makaruni;

- nazwy kosmetyków i środków do pielęgnacji: puder, sapun 'mydło', šampon;

- nazwy środków transportu: motorin 'motorówka', tonobil, trajekt 'prom';

- nazwy naczyń i narzędzi kuchennych: pijat, pinjatica, škudela 'głęboki talerz';

- nazwy mebli: fotelja, tapet 'dywan', tavela 'stół';

- elementy ubioru: čizma, mudantine 'majtki', šudar 'chusta'.

\section{Czasowniki}

Analizując czasowniki, postanowiłam podzielić je na trzy grupy, zgodnie z propozycją autorów Priručnej gramatiki hrvatskoga književnog jezika (Gramatika 1979: 143). Autorzy tej gramatyki wyróżniają: glagoli radnje, glagoli zbivanja oraz glagoli stanja. Są to więc czasowniki, które oznaczają:

1) akcję wykonywaną z pełną świadomością;

2) wydarzenie, które nie jest zależne od np. ludzkiej woli;

3) stan, któremu podlega podmiot.

Do pierwszej grupy można zaliczyć największą liczbę wyrazów (71 haseł, tj. 81,6\% wszystkich czasowników obcego pochodzenia), np.: kolpat 'uderzyć', lešat 'gotować', protestirat. Druga grupa jest znacznie słabiej reprezentowana (11 haseł, tj. 12,65\%), np.: paničarit 'panikować', rebambit 'zdziecinnieć'. Do trzeciej grupy należy jedynie 5 haseł (tj. 5,75\%), np.: komodat 'być wygodnym', parit.

\section{Przymiotniki}

Zgodnie z propozycją Priručnej gramatiki hrvatskoga književnog jezika wyróżniam trzy grupy znaczeniowe przymiotników (Gramatika 1979: 102):

1) opisni pridjevi, a więc przymiotniki opisujące cechy;

2) gradivni pridjevi, a więc przymiotniki wskazujące na materiał, z którego dany przedmiot został wykonany;

3) posvojni pridjevi, a więc przymiotniki dzierżawcze.

Najliczniej reprezentowana jest pierwsza grupa (55 hasel, tj. 88,71\% wszystkich przymiotników obcego pochodzenia), np.: frižak 'świeży', kurjožast 'ciekawski', štuf. Do drugiej grupy zaliczyłam 3 hasła (tj. 4,84\%): baršunast, parafinski, plastičan. Do trzeciej grupy należą 4 hasła (tj. 6,45\%): otelski, plebejski, ricinusov, veterinarski. $\mathrm{W}$ podziale nie uwzględniono imiesłowów przymiotnikowych. 


\section{Przysłówki}

Priručna gramatika hrvatskoga književnog jezika zakłada, iż przysłówki mogą wyrażać (Gramatika 1979: 138-139):

1) okoliczności danego wydarzenia, w tym m.in.:

- miejsce (ća 'stąd');

- czas (deboto, morgen);

- sposób (wynotowano 12 przysłówków, np.: ewentualno, furijano 'ze złością', pačifiko 'spokojnie');

- powód (protestno 'w ramach protestu)';

2) stopień intensywności wydarzenia (duplo 'podwójnie');

3) niesprecyzowaną bliżej liczbę osób, zwierząt, rzeczy itp. (brak przykładów u Smoje).

\section{Podsumowanie i wnioski}

Nieskodyfikowany język mieszkańców środkowej Dalmacji nigdy nie stawiał tak silnego oporu napływowi wyrazów obcego pochodzenia jak język standardowy. Dlatego też w gwarze miejskiej Splitu leksyki obcego pochodzenia jest dużo. Choć Smoje pisze językiem potocznym, to jednak fakt szerokiego zastosowania $w$ analizowanym tekście wyrazów obcego pochodzenia zdradza wykształconego i oczytanego autora, któremu nie są obce nawet najbardziej skomplikowane zagadnienia natury społecznej, politycznej i gospodarczej. Oprócz leksyki włoskiej, do gwary miejskiej Splitu przenikało także słownictwo niemieckie, francuskie, węgierskie, angielskie, tureckie oraz oczywiście greckie i łacińskie. Zapożyczenia z tych języków nie tylko umożliwiały językowi nadążanie za postępem cywilizacyjnym, ale też ułatwiały porozumiewanie się i wzbogacały rodzime słownictwo o nowe, bardziej precyzyjne środki wyrazu. Wiele zapożyczeń, głównie włoskich, spełnia w tekście także inną, dodatkową funkcję - stały się narzędziem literacko-artystycznej stylizacji.

Po italianizmach drugie miejsce pod względem liczby haseł zajmują internacjonalizmy właściwe, tj. pożyczki z języków klasycznych. Wyrazy te zajmują również drugie miejsce pod względem frekwencji użycia w tekście, co jest zrozumiałe w językach wszystkich narodów europejskich, będących spadkobiercami imponującej kultury helleńskiej i rzymskiej.

Trzecie miejsce należy do galicyzmów, które przenikały do języka chorwackiego w epoce największej popularności języka francuskiego na europejskich salonach.

Kolejne miejsce zajmują zapożyczenia sztuczne i anglicyzmy. Uzasadnienia popularności jednych i drugich należałoby z pewnością szukać w dzisiejszej globalizacji, która otwiera szerokie horyzonty przed słownictwem międzynarodowym i stwarza nową szansę językowi mediów - angielskiemu.

Ze względu na silny społeczny, a więc także i językowy, opór wobec germanizacji, niewiele odnajdziemy w tekście zapożyczeń niemieckich. Podobna sytuacja miała miejsce w przypadku turcyzmów i madziaryzmów - pożyczek z języków okupantów Chorwacji i Dalmacji. 
Wśród zapożyczeń zdecydowanie przeważają rzeczowniki, w których dominują nazwy zjawisk abstrakcyjnych oraz nazwy przedmiotów, a więc tych elementów świata pozajęzykowego, które otaczały autora w chwili opisywania jego codziennej rzeczywistości.

Zaprezentowane obliczenia pozwalają stwierdzić, iż wyrazy obcego pochodzenia mają większe znaczenie dla słownika utworu niż jego tekstu. Zdecydowaną większość zapożyczeń stanowią więc wyrazy rzadkie, bardzo rzadkie oraz wyjątkowe.

Derywaty od zapożyczeń świadczą o wysokim stopniu zasymilowania pożyczek przez system i trwałym ,zadomowieniu się” ich w gwarze miejskiej Splitu.

\section{Bibliografia}

Anić V., 1998, Rječnik hrvatskoga jezika, Zagrzeb.

Bender A., Żak K., 1998, Słownik niemiecko-polski i polsko-niemiecki, Warszawa.

Brborić V., 1996, Turcizmi u udžbenicima srpskog jezika za više razrede osnovne škole, w: O leksičkim pozajmljenicama. Zbornik radova sa naučnog skupa Strane reči i izrazi u srpskom jeziku, sa osvrtom na isti problem u jezicima nacionalnih manjina, red. M. Ivić, Subotica-Belgrad, s. 341-349.

Cieśla H., Jamrozik E., Kłos R., 2001, Wielki słownik włosko-polski, Warszawa.

Filipović R., 1990, Anglicizmi u hrvatskom ili srpskom jeziku, Zagrzeb.

Glovacki-Bernardi Z., 1993, O njemačkim elementima u zagrebačkom govoru i hrvatskom književnom jeziku, w: Rječnik i društvo. Zbornik radova sa znanstvenog skupa o leksikografiji i leksikologiji održanog 11-13.X.1989. u Zagrebu, red. R. Filipović, B. Finka, B. Tafra, Zagrzeb, s. 93-96.

Gojmerac M., 2001, Hrvatski i njemački, w: Zbornik zagrebačke slavističke škole. Trideset godina rada, red. S. Botica, Zagrzeb, s. 181-191.

Gramatika - Barić E., Lončarić M., Malić D., Pavešić S., Peti M., Zečević V., Znika M., 1979, Priručna gramatika hrvatskoga književnog jezika, Zagrzeb.

Hamm J., 1961, Cakawizm na wybrzeżu adriatyckim, w: Z badań nad językami Jugosławii, red. H. Olszewska, Warszawa, s. 67-80.

Jerković J., 1996, Mađarizmi u rečniku srpskohrvatskog književnog jezika, w: O leksičkim pozajmljenicama. Zbornik radova sa naučnog skupa: Strane reči i izrazi u srpskom jeziku, sa osvrtom na isti problem u jezicima nacionalnih manjina, red. M. Ivić, Subotica-Belgrad, s. 172-181.

Klaić B., 2001, Rječnik stranih riječi, Zagrzeb.

Muljačić Ž., 1962, Dalmatinski elementi u mletački pisanim dubrovačkim dokumentima 14. stoljeća, „Rad Jugoslavenske Akademije Znanosti i Umjetnosti” 327, Zagrzeb, s. 237-380.

Novaković-ŠSašić D., 1996, Engleske reči u Beogradskoj dnevnoj štampi, w: O leksičkim pozajmljenicama. Zbornik radova sa naučnog skupa Strane reči i izrazi u srpskom jeziku, sa osvrtom na isti problem u jezicima nacionalnih manjina, red. M. Ivić, Subotica-Belgrad, s. 306-313.

Peco A., 1986, Germanizmi u Vukovu srpskom rječniku iz 1852., „Filologija” 14, Zagrzeb, s. $271-282$.

Perić I., 1997, Povijest Hrvata, Zagrzeb.

Phillips J., Oxford Wordpower, 1997, Słownik angielsko-polski z indeksem polsko-angielskim, Oxford. 
Pieńkos E., Pieńkos J., Zaręba L., Dobrzyński J., 1995, Wielki słownik polsko-francuski, Warszawa.

Podhorodecki L., 2000, Jugosławia. Dzieje narodów, państw i rozpad Federacji, Warszawa.

Pranjković I., 2001, Hrvatski i klasični jezici, w: Zbornik zagrebačke slavističke škole. Trideset godina rada, Zagreb, s. 156-163.

Pranjković I., 2002, Hrvatski i orijentalni jezici, w: Zbornik zagrebačke slavističke škole 2001, Zagrzeb, s. 16-28.

Rečnik srpskohrvatskog književnog jezika, 1967, Nowy Sad-Zagrzeb.

Reychman J., 1947, W sprawie zapożyczeń węgierskich w polszczyźnie, „Język Polski” XXXI, s. 203-211.

Samardžija M., 1995, Leksikologija s poviješću hrvatskog jezika u 20. stoljeću, Zagrzeb.

Skok P., 1971, Etimologijski rječnik hrvatskoga ili srpskoga jezika, Zagrzeb.

Skok P., 1938, Prilozi proučavanju turcizama u srpskohrvatskom jeziku, „Slavia” XV, z. 2, s. 166-190.

Skowronek J., Tanty M., Wasilewski T., 1977, Historia Słowian południowych i zachodnich, Warszawa.

Smółkowa T., 1974, Słownictwo i fleksja „Lalki” Bolesława Prusa. Badania statystyczne, Wrocław.

Sočanac L., 2004, Hrvatsko-talijanski jezični dodiri, Zagrzeb.

Varga D., 2001, Hrvatski i romanski jezici, w: Zbornik zagrebačke slavističke škole. Trideset godina rada, Zagrzeb, s. 174-180.

Vinja V., 1986, Hibridni rezultati jezičnih dodira, „Filologija” 14, Zagrzeb, s. 419-432.

Witaszek-Samborska M., 1993, Zapożyczenia z różnych języków we wspótczesnej polszczyźnie, Poznań.

\title{
KARINA GIEL
}

\section{Middle Dalmatian language contacts in Pasje novelete by Miljenko Smoje. Loan words in the urban dialect of Split}

\begin{abstract}
This article has been written following a thesis in which I analyse borrowings from foreign languages in the urban dialect of Split, with references to Pasje novelete by Miljenko Smoje. To this end, I have conducted a lexical and etymological survey on the vocabulary excerpted from the book and I have delved into linguistic statistics. Consequently, I have documented the number and frequency of words borrowed from foreign languages. I also present a detailed calculation of the relationships between the borrowings and juxtaposed with the native vocabulary. In addition, I present a historical outline of the contacts between Croatian and other languages. I describe their intensity and the recent situation as reflected in the lexical area of the Croatian language. Finally, I make several comments on the semantic characteristics of loan words.
\end{abstract}

Keywords: borrowings, etymology, frequency, language contact, loan words, statistics, urban dialect, vocabulary. 